\title{
CROSSTOLERANT EFFECT OF SALT PRIMING AND VIRAL INFECTION ON NICOTIANA BENTHAMIANA
}

\author{
Dildabek A., Ilyasova B., Stamgaliyeva Z., Madirov A., Kassenova S., \\ Zhangazin S., Massalimov Zh., Akbassova A. \\ L.N. Gumilyov Eurasian National University, Department of Biotechnology and \\ Microbiology \\ 2, Satpayev str., Nur-Sultan, 010000, Kazakhstan \\ a.j.alua@gmail.com
}

\begin{abstract}
Currently, the salinization of soil one of the factors, which determine the productivity of crop plants. Under severe conditions, plants reveal the retardation in growth of shoots and roots, the decrease of productivity, because of biochemical and physiologicaleffects of salt high concentrations. To avoid any severe effect of biotic and abiotic stress is applied to the method of seed priming. Primed seed preserves the resistance signaling pathway for upcoming stress conditions. During biotic and biotic stress firstly accumulates reactive oxygen species which are the secondary messenger molecules in many signaling pathway of plant organisms. Excessive amounts of reactive oxygen species lead to macromolecules damage, such as lipids of cell walls, proteins, nucleic acids. To overcome the severe effect, plants evolved enzymatic and non-enzymatic systems of protection. The crucial enzymes are catalase, aldehyde oxidase, superoxide dismutase. The main components of the non-enzymatic antioxidant system are vitamins, low molecular mass substances such as glutathione. The phenomenon "cross-tolerance" suggests the resistance of plant organism to one stress by the exposure to another one. Early exposure salt stress to Nicotiana benthamiana leads to resistance to viral infection, change the activity of antioxidant enzymes (catalase, aldehyde oxidase). The analysis of viral particles revealed the decrease of viral particles content in salt primed plants.

Keywords: salinity, priming, viral infection, cross-tolerance, reactive oxygen species.
\end{abstract}

\section{INTRODUCTION}

Salinity is one of the crucial environmental factors, which leads to crop productivity restrictions because the majority of crops are sensitive to salinization caused by high levels of salts in the soil. The area affected by high salt concentration grows every day. The loss of yield among cultural plants ranges from $20 \%$ to $50 \%$, and the causes of such losses are mainly drought and severe salinization of the soil [1].

Elucidation of the adaptation mechanisms of plant organisms that allow them to survive under saline conditions is an important direction in the physiology of plant resistance [2].

In consequence of review the effect of medium salinity, the following factors are identified: the difficulties of water supply in the whole plant and, therefore, negative changes in the functioning of osmoregulation mechanisms; imbalance in the mineral 
composition of the medium, resulted in disturbances of the plants' mineral nutrition; stress on severe salinization; toxicity.

Plants respond to severe environmental conditions, such as abiotic and biotic stress bythe generation of active oxygen species. For the majority of organisms the oxygen presence plays a crucial role in cell energetics, because of nutrients oxidation capability.

Molecular oxygen is not toxic for cells, but products of oxygen incomplete oxidation suggest the danger represents incomplete oxidation of oxygen products: peroxide compounds, superoxide radicals, singlet oxygen, and others. Due to the high biological activity they are named reactive oxygen species (ROS). The appearance of ROS is caused by the fact that molecular oxygen $\left(\mathrm{O}_{2}\right)$ can intercept electrons from certain electron transport chain carriers [3]. As a result of a single-electron reduction of the oxygen molecule, superoxide radical or anion radical is formed. Superoxide radical is a charged particle surrounded by water molecules. Therefore, $\mathrm{O}_{2}$ cannot pass the membrane, it is "locked" in the cell and becomes the source of other ROS forms, for example, hydrogen peroxide. Hydrogen peroxide, in turn, is restored and gives a hydroxyl radical. Hydroxyl radicals oxidize almost any substance of the cell, including DNA.

Reactive oxygen species take part in defensive reactions, for example, under the action of pathogens, and also serve as secondary intermediaries in signaling. Cell protection is ensured by the operation of the antioxidant system, which can be accomplished by enzymatic and non-enzymatic pathways. The main method of protection against ROS is inactivation. This is achieved by the work of special enzymes: superoxide dismutases, catalases, peroxidases [4].

Superoxide dismutase (SOD) is an enzyme that is widely distributed in nature. The active center of SOD contains metal ions (copper, iron, manganese, zinc). Thus, $\mathrm{Mn}-\mathrm{SOD}$ is contained in mitochondria, Fe-SOD in chloroplasts, and $\mathrm{Cu}-\mathrm{Zn}$ SOD in cytoplasm and peroxysomes. SOD is present in all aerobic organisms and serves to effectively remove superoxide radicals. SOD catalyzes the reaction of the conversion of two anion radicals to hydrogen peroxide $\left(\mathrm{H}_{2} \mathrm{O}_{2}\right)$ and molecular oxygen. Catalase breaks down hydrogen peroxide with the formation of water and molecular oxygen, and peroxidases restore hydrogen peroxide with special substrates, for example, a glutathione[5]. Catalases are a tetrameric heme-containing enzyme found in all aerobic organisms. It is one of the most active natural catalysts that break down hydrogen peroxide $\left(\mathrm{H}_{2} \mathrm{O}_{2}\right)$. Catalase is a tetramer of four polypeptide chains, each of which consists of more than 500 amino acids [6]. It contains four groups of heme porphyrin, which contribute to the interaction of the enzyme with hydrogen peroxide. As a result of the interaction, catalase converts $\left(\mathrm{H}_{2} \mathrm{O}_{2}\right)$ into the water and molecular oxygen [7].

Catalase activity depends on many factors, one of which is salicylic acid. Thus, SA can inhibit the activity of catalase under the influence of a pathogen on plants, as a result of which the accumulation of $\mathrm{H}_{2} \mathrm{O}_{2}$ in the lesion increases to induce the expression of resistance genes associated with systemic acquired resistance [8].

The antioxidant system also includes low molecular weight antioxidant substances capable of reacting with ROS without the participation of enzymes. Such substances include carotenes, vitamins (A, E, C), others. Thus, ascorbic acid (vitamin C) can react with superoxide and hydroxyl radicals and thereby reduce their concentration in the cell. The degree of damage from ROS depends on the effective operation of the antioxidant system and is determined by the resistance of plants. In resistant plants, the activity of antioxidant enzymes and the content of vitamins $\mathrm{E}$ and $\mathrm{C}$ are higher. It has been shown that the introduction of SOD into tissues suppresses the formation of excess ROS and reduces the death of cells due to the action of pathogens[9].Transgenic plants with 
increased activity of SOD turns out to be more resistant to many stress factors, including water deficiency.

Seed priming induces various protective mechanisms under stress[10].High salinity results ina production loss of 1.5 million hectares of land each year [11].Seed germination and seedling growth are two critical steps for creating crops. These stages are most sensitive to abiotic stress [12]. The seed priming method is designed to alter the processes associated with germination. [13].The seed priming process includes, firstly, exposure to a factor for resistance to future stress exposure [14].

Priming is a procedure that moisturizes seeds in a specific environment, after which the seeds dried so that germination processes begin [15].This process improves the protective mechanisms of germination, which enable seeds to overcome environmental stresses[16].

TBSV is a virus that is a species of the Tombusvirus family, the genus Tombusviridae. TBSV and the suppressor protein P19 are effective tools for studying the molecular interactions of plants and viruses [17].Currently, the Tombusviridae virus family includes thirteen viral genera that contain single chain $(+)$ ssRNA and isometric virions [18]. According to the latest data from the International Committee on Taxonomy of Viruses (ICTV), 71 representatives of the Tombusviridae family are registered, which infect both monocotyledonous and dicotyledonous plant representatives[19]. In plants, one of the common mechanisms of plant resistance is RNA-interference. In plants, RNA interference acts as an antiviral system, so successful viral infection requires inhibition of RNAi. Many viral suppressors have been identified but the molecular basis for RNAi suppression is still poorly understood. P19 also inhibits RNAi in the heterologous Drosophila in vitro system, preventing the inclusion of siRNAs in the RISC complex. During infection, p19 markedly reduces the number of free siRNAs in cells, forming P19-siRNA complexes, thereby making siRNAs inaccessible to effector complexes of the RNAi mechanism. Besides, the results suggest that P19-mediated siRNA binding in virus-infected cells blocks the spread of mobile, systemic RNAi [20].

\section{Materials and methods}

Seed priming. Previously, the seeds of $N$. benthamiana were sterilized with a solution of $25 \mathrm{ml}$ of sodium hypochlorite $(\mathrm{NaClO})$ and $25 \mathrm{ml}$ of distilled water for 10 minutes, then they were washed three times with distilled water and dipped in a solution of $70 \%$ alcohol for 10 seconds, then rinsed again with distilled water. After drying, the seeds were primed, soaked in $25 \mathrm{mM}, 50 \mathrm{mM}, 100 \mathrm{mM} \mathrm{NaCl}$ solutions at room temperature for 4, 6, 8 hours, and the seeds of the control group were soaked in distilled water. In the end, the seeds were washed with distilled water, dried for 10 hours. Then, 12 seeds of each treatment and control variant were sown in pots with sterilized soil.

Plant and virus materials. Seeds of plants Nicotiana benthamianawere grown in the soil containing biohumus and basic nutrients such as nitrogen $\left(\mathrm{NH}_{4}+\mathrm{NO}_{3}\right) 150 \mathrm{mg} / \mathrm{l}$, phosphorus $\left(\mathrm{P}_{2} \mathrm{O}_{5}\right) 270 \mathrm{mg} / \mathrm{l}$, potassium $\left(\mathrm{K}_{2} \mathrm{O}\right) 300 \mathrm{mg} / \mathrm{l}$, with a $\mathrm{pH}$ of $6.0-6.5$ in the greenhouse. The greenhouse is equipped with white-fluorescent lamps of $230 \mathrm{~V}$, a timer with a 16-hour operation, and a temperature regime of $25 / 20^{\circ} \mathrm{C}$ (day and night) with a humidity of $80 \%$. Plants were watered 3 times a week with $50 \mathrm{ml}$ of water. Plants of 25-35 days of the same size were selected to provide equal experimental conditions. 20 $\mu \mathrm{l}$ of an inoculation buffer $(10 \mathrm{mM}$ sodium phosphate buffer, $\mathrm{pH} 6.9)$ containing virions and carborundum $(\mathrm{d}=0,037 \mathrm{Mm})$ was applied on the surface of the middle leaves of each plant. 
Plants inoculation by TBSV RNA transcripts. For plants inoculation in vitro generated transcripts of full-length TBSV cDNAs were used [21,22]. For this, plasmids containing the inserts were linearized at the $3^{\prime}$-end of the viral cDNA sequence by restriction SmaI enzyme digest. Transcripts were synthesized using T7 RNA polymerase, and the resulting transcripts were used for the inoculation of plants as previously described [23]. Control plants were mock-inoculated by using phosphate buffer without viral RNA. Healthy and infected plants were grown separately in the same conditions.

Western blot analysis. Protein samples extracted from mock-inoculated and TBSV infected plants were separated by $12 \%$ SDS - polyacrylamide gel electrophoresis (PAGE) and transferred to nitrocellulose membrane (Osmonics, Westborough, MA). After transfer the membranes were stained with Ponceau S (Sigma, St. Louis, MO) for verification of protein transfer efficiency. The resulting membrane was incubated with diluted primary antibodies (1:5000) raised against P19 TBSV protein. Alkaline phosphatase-conjugated to goat anti-rabbit antiserum (Sigma) was used as a secondary antibody at a dilution of 1:3000, and the immune complexes were visualized by hydrolysis of tetrazolium-5-bromo-4-chloro-3-indolyl phosphate as the substrate.

Detection of TBSV virions in inoculated plants. Antibodies against TBSV virions were received from BALB/c mice by long period immunization. The immunization was carried out by Freund's complete and incomplete adjuvants [24]. For immunization $200 \mathrm{ml}$ of virions and $200 \mathrm{ml}$ of adjuvant were added. Upper noninoculated leaves were analyzed for the presence of TBSV virions. For each experiment samples were combined from three different plants. Samples from healthy and inoculated by wild type TBSV plants were separately homogenized in TRIS/EDTA (TE) buffer in ratio 1/2 (sample/buffer) on ice. After homogenization, all samples were centrifuged at $12000 \mathrm{rpm}(4 \mathrm{C})$ for $20 \mathrm{~min}$ and the resulting supernatant was transferred in the new tubes. Then $30 \mathrm{ml}$ of each sample were mixed with $6 \mathrm{X}$ Loading buffer and separated in $1 \%$ agarose gel with ethidium bromide for $40 \mathrm{~min}$ with Tris/Borate/ EDTA buffer. Viral particles were detected in agarose gel using UV light. To detect TBSV virions, a capillary transfer onto the nitrocellulose membrane was performed followed by immunostaining with TBSV virion-specific polyclonal antibodies. Membrane blocking and visualization of phosphatase activity after incubation with antibodies, were performed like it was described for Western blotting.

Samples preparation for non-denaturing gel electrophoresis and in vitro assays. Freshly collected upper non-inoculated leaves of N. benthamiana were detached from plants, weighted and then frozen in liquid nitrogen, grounded in an ice-cold mortar with cold extraction buffer in 1:2 ratio (w/v). For each experiment samples were combined from three different plants. The buffer contained $250 \mathrm{mM}$ Tris- $\mathrm{HCl}(\mathrm{pH} 7.5)$, $250 \mathrm{mM}$ Sucrose, $0.05 \mathrm{mM}$ Sodium molybdate dihydrate $(\mathrm{Na} 2 \mathrm{MoO} 4 \$ 2 \mathrm{H} 2 \mathrm{O}), 1 \mathrm{mM}$ ethylenediaminetetraacetic acid (EDTA), $4 \mathrm{mM}$ 1,4-Dithiothreitol (DTT), $5 \mathrm{mM} \mathrm{L-}$ cysteine, $0.001 \mathrm{mM}$ aprotinin, $0.1 \mathrm{mM}$ phenylmethanesulfonyl fluoride (PMSF) and $0.001 \mathrm{mM}$ pepstatin. After homogenization all samples were centrifuged at $12000 \mathrm{rpm}$ $\left(4{ }^{\circ} \mathrm{C}\right)$ for $20 \mathrm{~min}$. The resulting supernatant was transferred to the new tubes and kept on ice until the non-denaturing PAGE, which was performed as previously described [25].

Analysis of AO in gel activity. After non-denaturing electrophoresis resulting gels were rinsed with distilled water and stained in a substrate mixture, containing 0.1 M TRIS-HCl, $\mathrm{pH} 7.4,1 \mathrm{mM}$ indole-3-carboxaldehyde, $0.5 \mathrm{mM}$ thiazolyl blue 
tetrazolium bromide (MTT) as an indicator and $0.5 \mathrm{mM}$ phenazine methosulfate (PMS) as electron carrier at $37 \mathrm{C}$ for $45 \mathrm{~min}$ [26]. To determine the ability of AO to produce superoxide anions using aldehydes, PMS was excluded from the substrate solution. AO production of $\mathrm{O}_{2}^{-}$using NADH as a substrate was tested as it was described before with $0.25 \mathrm{mM}$ NADH instead of indole-3-carboxaldehyde [27].

Analysis of CAT in gel activity. After non-denaturing electrophoresis resulting gels with leaves samples of mock- and TBSV inoculated $N$. benthamiana plants were rinsed with distilled water 3 times and then soaked in $0.003 \% \mathrm{H}_{2} \mathrm{O}_{2}$ solution for $15 \mathrm{~min}$. Gels were then stained in a solution of $2 \%$ potassium ferricyanide and $2 \%$ ferric chloride until the appearance of the achromatic bands [28].

\section{RESULTS}

The effect of salt priming on the growth of $N$. benthamiana. After priming, $N$. benthamiana seeds were grown on sterilized soil with 12 seeds each for further direct assessment of the effect of various concentrations of sodium chloride on physiological parameters (\% seed germination, growth rate, germination index) and morphometric parameters (root and stem lengths). On the 10th day after planting, ascended plants from 12 planted seeds were counted (Figure 1). The results of 4 hours of seed priming in 25 $\mathrm{mM}, 50 \mathrm{mM}, 100 \mathrm{mM}$ on day 10 of the experiment are presented below in figures 1 and 2.

control (11 from 12)

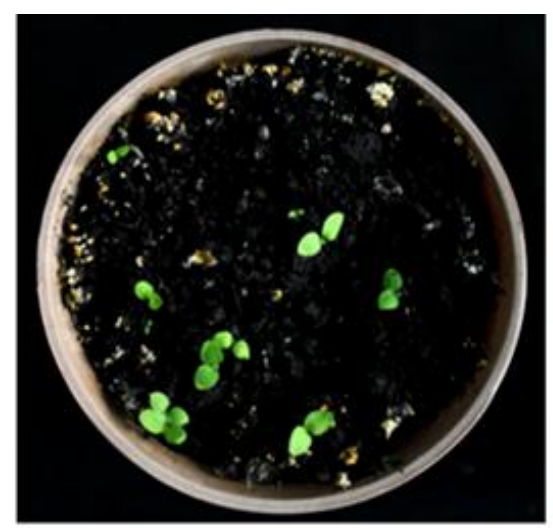

$50 \mathrm{mM}$ (10 from 12)

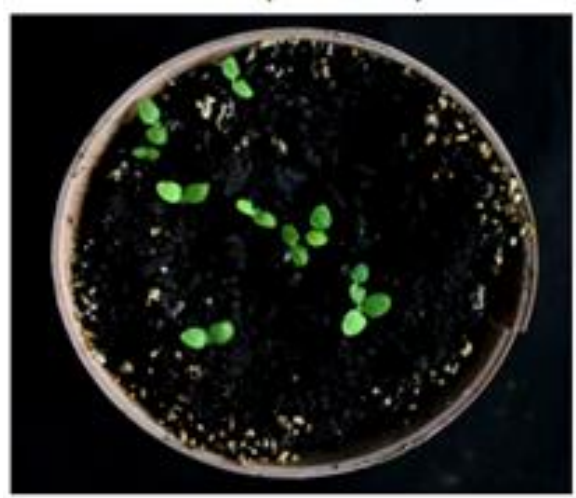

Fig.1. The growth of $N$. benthamiana after salt priming with various concentrations of $\mathrm{NaCl}$ on day 10 of cultivation
$25 \mathrm{mM}$ (11 from 12)

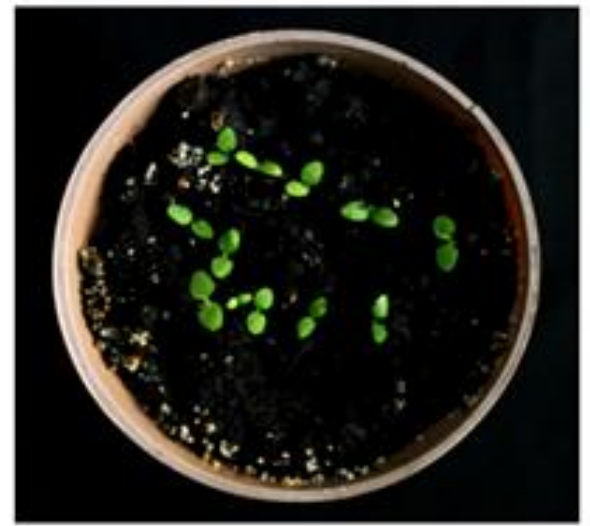

$100 \mathrm{mM}$ (12 from 12)

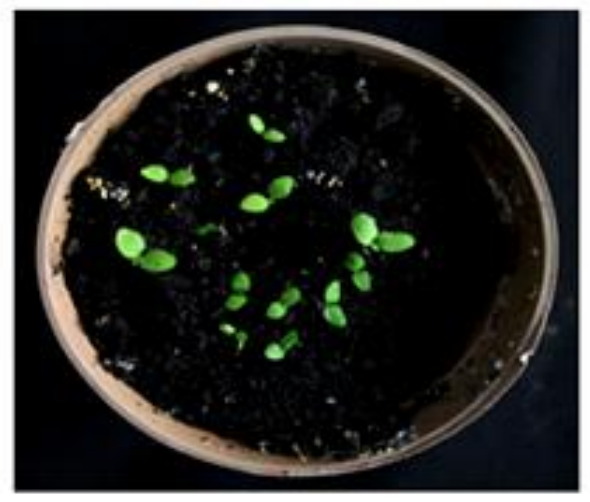


A
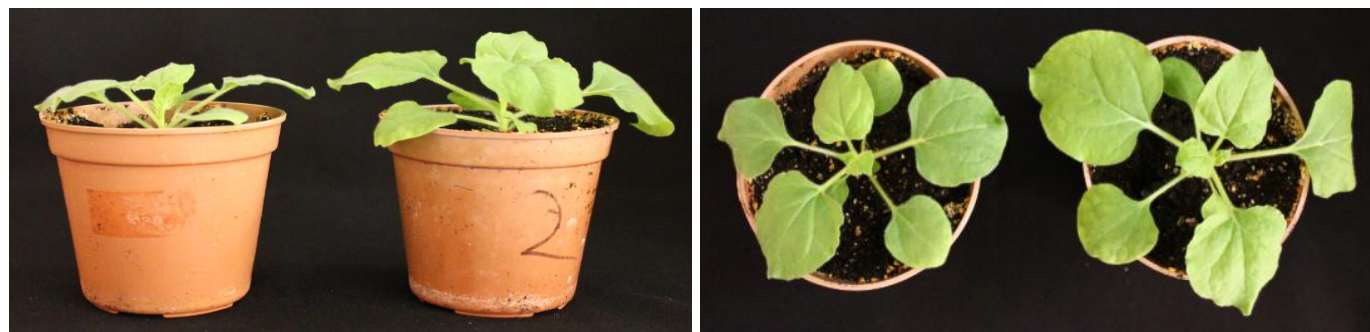

$\mathrm{B}$
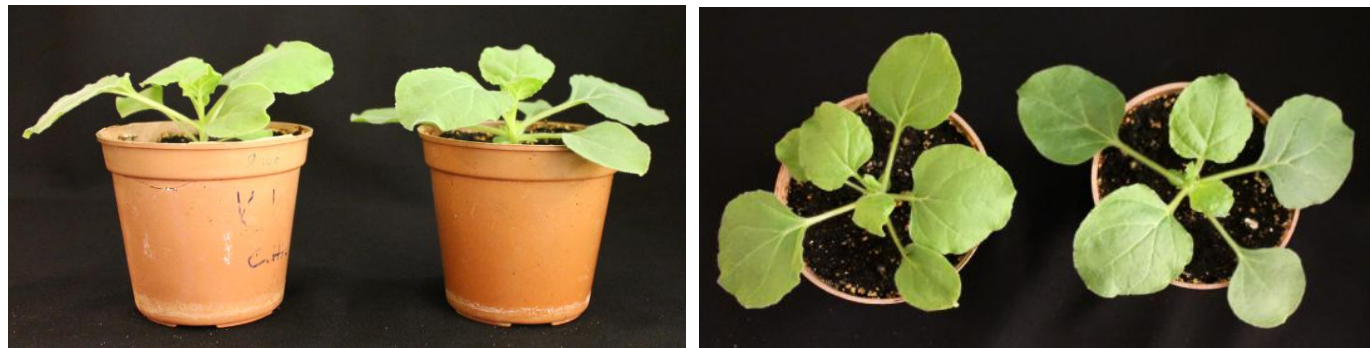

$\mathrm{C}$
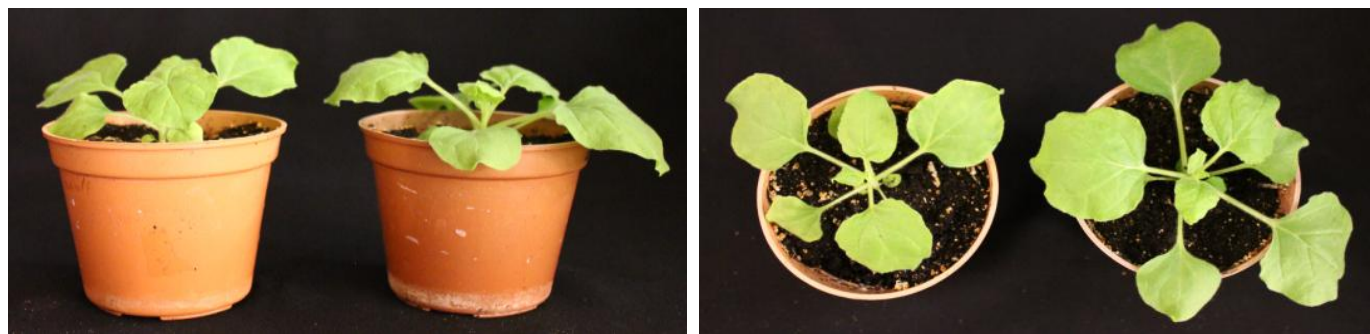

$\mathrm{D}$
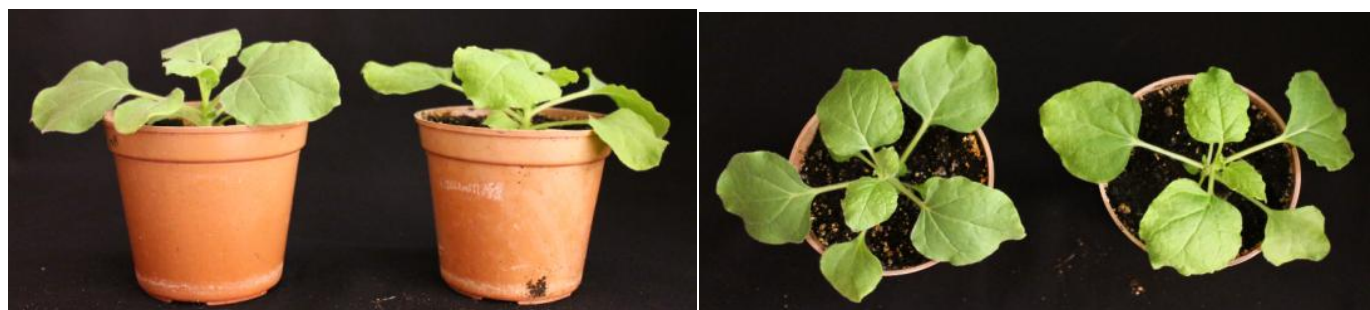

A - distilled water priming (control plants); B - $25 \mathrm{~mm}$ salt priming; C - $50 \mathrm{mM}$ salt priming; D - 100 mm salt priming.

Fig. 2. The effect of 4 hour NaClpriming on the growth of $N$. benthamiana on day 30 of cultivation

As a result of the priming of $N$. benthamiana seeds at 4 and 6-hour primings, no significant difference in plant growth was observed. Slight growth retardation was observed when priming with 50 and $100 \mathrm{mM}$ salt as compared to control and primed with $25 \mathrm{mM}$ salt plants. And at 8 hours of priming with various concentrations of salts, N.benthamiana seeds did not germinate.

The effect of salt priming on plants antiviral resistance. Plants primed with various concentrations of salts of $N$. benthamiana at the age of 30 days were inoculated in vitro with wild-type TBSV transcripts (Figure 3). 

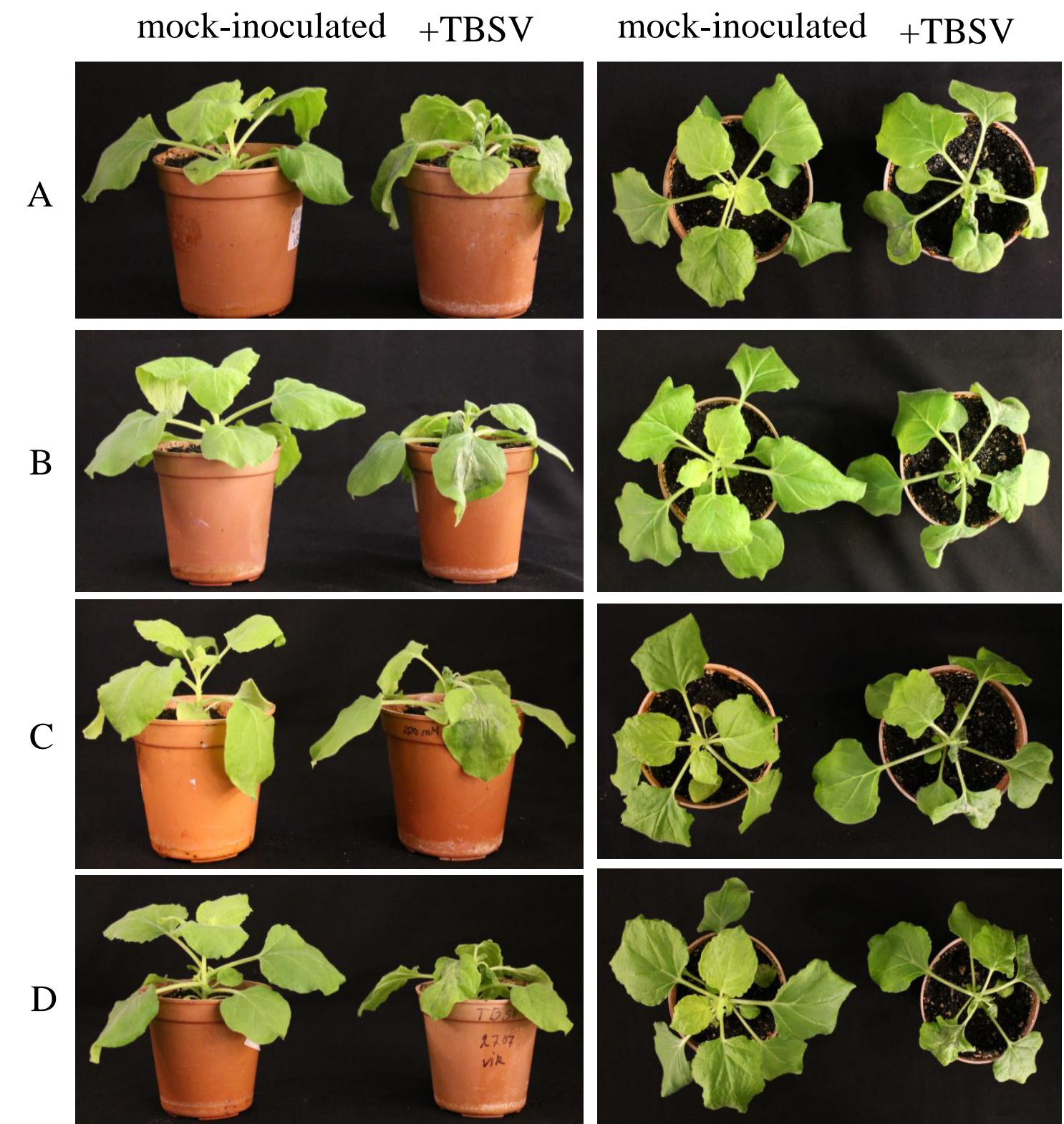

A - distilled water priming (control plants); B - $25 \mathrm{~mm}$ salt priming; C - $50 \mathrm{mM}$ salt priming; D - 100 mm salt priming.

Fig. 3. The manifestation of symptoms of TBSV infection with preliminary salt priming of $N$. benthamiana by $7 \mathrm{dpi}$.

To detect viral infection, an express method for analyzing the presence of virions was performed (Figure 4).

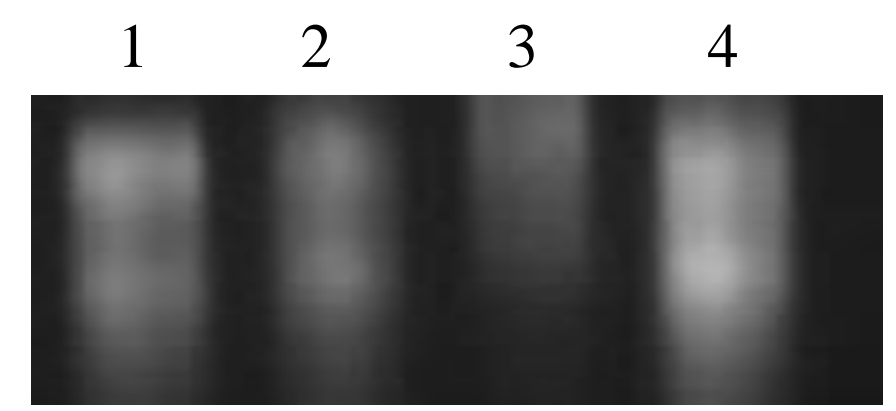

1- priming with distilled water, TBSV inoculated; 2 - $25 \mathrm{mM}$ salt priming, TBSV inoculated; 3 - 50 $\mathrm{mM}$ salt priming, TBSV inoculated; $4-100 \mathrm{mM}$ salt priming, TBSV inoculated.

Fig.4. Express detection of TBSV virus particles in infected plants 
According to the result of analysis of the presence of viral particles in infected plants in plants previously primed with $50 \mathrm{mM} \mathrm{NaCl}$, less than other plants. Corresponding results were also shown by visual symptoms of a viral infection (Figure 4).

The effect of salt priming of seeds on oxidative stress enzymes. Isoforms of the catalase enzyme and the aldehyde oxidase molybdoenzyme in the activation of an oxidative explosion during plant priming are studied. In this experiment, seeds preprimed using $25 \mathrm{mM}, 50 \mathrm{mM}, 100 \mathrm{mM} \mathrm{NaCl}$ were used. On the 35th day of their development, the plants were analyzed using native gel electrophoresis to determine the activity of the aldehyde oxidase and catalase enzymes (Figure 5, Figure 6).With an increase in the treated concentration of $\mathrm{NaCl}$, the activity of the aldehyde oxidase in the gel increases. The higher the concentration of $\mathrm{NaCl}$, the higher the activity of aldehyde oxidase compared with the control sample.With an increase in the treated concentration of $\mathrm{NaCl}$, the activity of catalase decreases compared with the control sample.
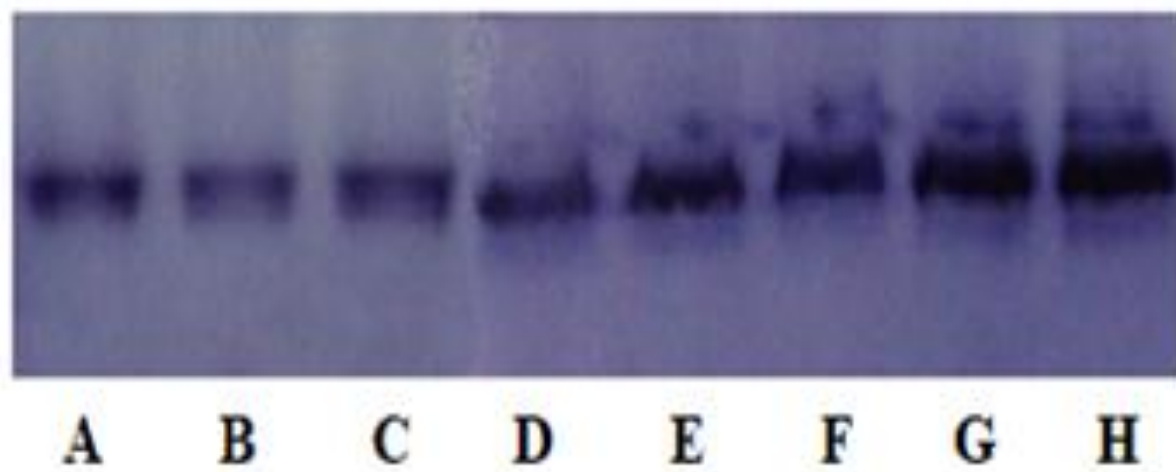

A - control plant distilled water primed; B - unprimed virus inoculated plant; $\mathrm{C}$ - $25 \mathrm{mM} \mathrm{NaCl}$ primed; $\mathrm{D}$ - virus inoculated, $25 \mathrm{mM} \mathrm{NaCl}$ primed; $\mathrm{E}$ - $50 \mathrm{mM} \mathrm{NaCl}$ primed; $\mathrm{F}-50 \mathrm{mM} \mathrm{NaCl}$ primed, virus inoculated; $\mathrm{G}$ - $100 \mathrm{mM} \mathrm{NaCl}$ primed; $\mathrm{H}$ - $100 \mathrm{mM} \mathrm{NaCl}$ primed, virus inoculated.

Fig.5. The effect of salt priming of seeds on aldehyde oxidase activity determination in gel
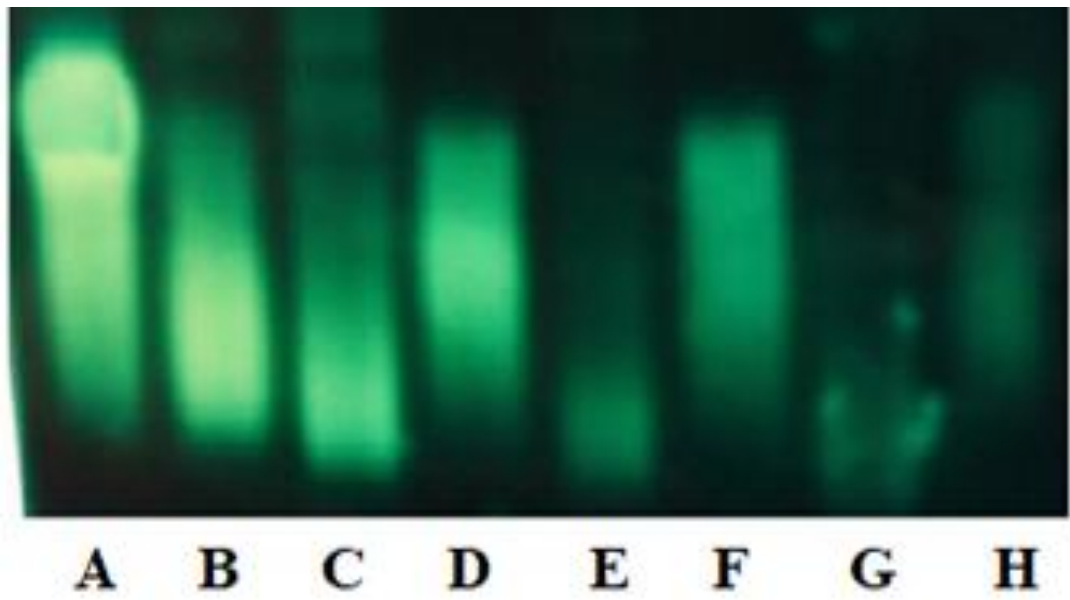

A - control plant distilled water primed; B - unprimed virus inoculated plant;

C - $25 \mathrm{mM} \mathrm{NaCl}$ primed; D - virus inoculated, $25 \mathrm{mM} \mathrm{NaCl}$ primed; $\mathrm{E}$ - $50 \mathrm{mM} \mathrm{NaCl}$ primed; F -50 $\mathrm{mM} \mathrm{NaCl}$ primed, virus inoculated; $\mathrm{G}-100 \mathrm{mM} \mathrm{NaCl}$ primed;

$\mathrm{H}-100 \mathrm{mM} \mathrm{NaCl}$ primed, virus inoculated.

Fig. 5. The effect of salt priming of seeds on catalase activity in gel

\section{DISCUSSION}

As mentioned before, seed priming prepares plants to overcome upcoming environmental stress. Proposed priming mechanisms include the occurrence of epigenetic changes, as well as the accumulation of transcription factors and inactive 
forms of signaling proteins. These mechanisms are modulated under the influence of stress, which leads to a more effective protective mechanism. This leads to faster and more uniform germination and the emergence of seedlings [29], improve crops under stressful conditions [30]. There are various methods of priming, namely hydropriming, halopriming, osmopriming, priming using the matrix.

The positive effects of priming under salinization conditions were noted in many cultures, such as tomato(SolanumlycopersicumL.), hot pepper (Capsicum annuum var. Acuminatum L.), lettuce (Lactuca sativa L.), corn (Zea mays L.) [31], okra (Abelmoschus esculentusL.), pea(Pisum sativum L.), pepper (Capsicum annuum L.), soy(Glycine max L.) [32].

Chemical treatment of plants using priming elicitors leads to the primary transmission of signals leading the plants to the priming stage, in which the signal network remains inactive. Exposure to environmental stress stimulates a genetically programmed defensive response along with activation of the primary signaling network associated with priming. This structure provides Spatio-temporal patterns of expression of genes and proteins associated with stress and ends with the reprogramming of a specific proteome, which ultimately leads to stress acclimatization. Despite the agronomic and environmental importance of priming, little is known about molecular mechanisms [33, 34].

It was confirmed that in the case of pretreatment of $\mathrm{NaCl}$ on Glycine max seedlings for acclimatization to subsequent salt stress, Deschampsia antarctica to cold stress. Interestingly, the primed state can also be induced in plants after the initial exposure to the agent, such natural or synthetic compounds as nitric oxide (NO).

[35], hydrogen peroxide $\left(\mathrm{H}_{2} \mathrm{O}_{2}\right)$ [36], hydrogen sulfide $\left(\mathrm{H}_{2} \mathrm{~S}\right), \beta$-aminobutyric acid (BABA), polyamines. Also, by analogy with the priming of vegetative parts of plants, water-based seed priming is widely used to revitalize and accelerate their germination [37].

Cross-tolerance is a phenomenon that explains how plant resistance to stress leads to resistance to a completely different kind of stress [38, 39], [40]. For example, it was shown that plants of the Tabacum family exposed to UV radiation showed resistance to the virus $[41,42]$.

In most stressful situations, signals are recognized by receptors, then the signals are transmitted to the generation of secondary messengers, also known as reactive oxygen species [43]. Secondary messengers can modulate extracellular calcium levels, usually initiating cascading protein phosphorylation reactions that lead to the activation of proteins directly involved in cellular defense.

In Arabidopsis, the expression of various transcripts has been studied using the microarray method and is evidence of the intersection of signals and the interaction of various biotic and abiotic stresses. Based on these results, the stress response genes were divided into 2 groups, the early stress response genes, which are mainly constitutive in most plants, and the late stress response genes, which mainly encode "effector proteins", like metabolic enzymes participate in physiological mechanisms adaptation [44].

The phenomenon "salinization and viral infection" is still poorly understoodbut interesting literature has already appeared based on the resistance of the plant $N$. benthamiana to the EMCV virus (Eggplant mottled crinkle virus) during plant development under salt stress [45], the resistance of plants N. Glutinosa to the TBSV virus under conditions like salt stress $(200 \mathrm{mM})$, darkness, and in a combination of salinization and lack of light (incubation period 48 hours) [46].

\section{CONCLUSIONS}


Studying the cross-tolerance phenomenon "salinization and viral infection" allowed us to draw the following conclusions.

1. The neutral effect of salt priming of $N$. benthamiana seeds on plant growth parameters was established;

2. It was determined that salt priming of $N$. benthamiana seeds inhibits viral infection. It was determined that at $50 \mathrm{mM} \mathrm{NaCl}$ priming of $N$. benthamiana, the accumulation of viral proteins, respectively, of viral infection is inhibited;

3. It was found that the higher the concentration of $\mathrm{NaCl}$ for priming with $N$. benthamiana viral infection, the higher the activity of aldehyde oxidase compared with the control sample;

4. It was found that, with an increase in the treated concentration of $\mathrm{NaCl}$ without viral infection, the activity of catalase decreases compared with the control sample, and with an increase in concentration during viral infection, the activity of catalase in the gel increases in comparison with control samples treated with $\mathrm{NaCl}$.

\section{Acknowledgemets}

This work was supported by the Ministry of Education and Science of the Republic of Kazakhstan (AP05135633 "The influence of virus protein determinants on acquired resistance of plants and generation plant seed material with pre-programmed resistance to the viral infection", AP05135013 "The involvement of ROS producing Mo-enzymes in root development and stress tolerance of plants" and BR05236574 "The development of advanced technologies to produce crops resistant to stress factors in utilizing adaptive mechanisms of plants"). 


\section{REFERENCES}

1.Shrivastava P., \& Kumar, R. 2015. Soil salinity: a serious environmental issue and plant growth promoting bacteria as one of the tools for its alleviation. Saudi journal of biological sciences, 2015, no. 22(2), pp. 123131.https://doi.org/10.1016/j.sjbs.2014.12.001. 
2.Gupta B., Huang B. 2014. Mechanism of salinity tolerance in plants: physiological, biochemical, and molecular characterization. International journal of genomics,vol. 2014, Available at: https://www.hindawi.com/journals/ijg/2014/701596/ (Accessed 3 April 2014).

3.Caverzan A., Casassola A., Brammer S. P. 2016. Antioxidant responses of wheat plants under stress. Genetics and molecular biology, 2016, vol. 39, no. 71, pp. 16.http://dx.doi.org/10.1590/1678-4685-GMB-2015-0109

4. Wojtaszek P. 1997. Oxidative burst: an early plant response to pathogen infection // Biochem J., 1997, vol. 322, no.3, pp.68192.https://doi.org/10.1042/bj3220681

5. Torres M.A. 2010. ROS in biotic interactions. Physiol. Plant, 2010,vol. 138, no. 4,pp. 414-429.https://doi.org/10.1111/j.1399-3054.2009.01326.x

6. Eising R., Trelease R., Ni W. 1989. Biogenesis of catalase in glyoxysomes and leaf-type peroxisomes of sunflower cotyledons. Arch. Biochem. Biophys, 1989, vol. 278, no.1,pp. 258-264.https://doi.org/10.1016/0003-9861(90)90256-X.

7. Lei R., Du Z., Qiu Y., Zhu S. 2016. The detection of hydrogen peroxide involved in plant virus infection by fluorescence spectroscopy. Luminescence, 2016, vol. 31, no. 5, pp. 1158-1165.https://doi.org/10.1002/bio.3090.

8. Chen Z., Silva H., Klessig D. F. 1993. Active oxygen species in the induction of plant systemic acquired resistance by salicylic acid. Science, 1993, vol. 262, pp. 1883-1886.https://doi.org/10.1126/science.8266079

9. Maffei M.E., Mithofer A., Boland W. 2007. Insects feeding on plants: rapid signals and responses preceding the induction of phytochemical release. Phytochemistry, 2007,vol. 68, no. 22-24, pp. 294659.https://doi.org/10.1016/j.phytochem.2007.07.016.

10. Stefania Caparrotta, Sara Boni, Cosimo Taiti, Emily Palm, Stefano Mancuso, Camilla Pandolf. 2018. Induction of priming by salt stress in neighboring plants.Environmental and Experimental Botany, 2018, vol. 147, pp. 261270.https://doi.org/10.1016/j.envexpbot.2017.12.017.

11. Qadir M. et al. 2014. Economics of salt-induced land degradation and restoration. Natural resources forum, 2014, vol. 38, no. 4, pp. 282295.https://doi.org/10.1111/1477-8947.12054

12. Yadav P.V., Kumari M., Ahmed Z. 2011.Seed priming mediated germination improvement and tolerance to subsequent exposure to cold and salt stress in capsicum. Research Journal of Seed Science, 2011, vol. 4, no. 3, pp. 125136.https://doi.org/3923/rjss.2011.125.136.

13. Paparella S., Araújo S. S., Rossi G., Wijayasinghe M., Carbonera D. , Balestrazzi A. 2015. Seed priming: state of the art and new perspectives.Plant Cell Reports, 2015, vol. 34, no. 8, pp. 1281-1293.https://doi.org/10.1007/s00299-015-1784-y

14. Georgia Tanou, Vasileios Fotopoulos and Athanassios Molassiotis. 2012. Priming against environmental challenges and proteomics in plants: update and agricultural perspectives. Frontiers in Plant Science, 2012, vol. 3, no. 216, pp. 15.https://doi.org/10.1002/pmic.200800985

15. Ghana S. Giri and William F. Schillinger. 2003. Seed Priming Winter Wheat for Germination, Emergence, and Yield. Alliance of Crop, Soil, and Environmental Science Societies, 2003, vol. 43, no. 6, pp. 21352141.https://doi.org/10.2135/cropsci2003.2135

16. Farooq M., Wahid A., Kobayashi N., Fujita D., Basra S. M. A., Plant Drought Stress: Effects, Mechanisms and Management. Sustainable Agriculture. Springer, Dordrecht, 2009. P. 153-188.https://doi.org/10.1007/978-90-481-2666-8_12. 
17. Yergaliyev T. M., Nurbekova Z., Mukiyanova G., Akbassova A., Sutula M., Zhangazin S., Bari A., Tleukulova Z., Shamekova M., Masalimov Z. K., Omarov R. T. 2016. The involvement of ROS producing aldehyde oxidase in plant response to Tombusvirus infection. Plant Physiol. Biochem, 2016, vol. 109, no. 10, pp. 3644.https://doi.org/10.1016/j.plaphy.2016.09.001

18. Kirgizova I. V., Ergaliev T. M. 2017.Rodovoj sostav virusov semejstva Tombusviridae. // Nauchnyj forum: Innovacionnaja nauka: sb. st. po materialam IV mezhdunar. nauch.-prakt. Konf. 2017, vol. 3, no. 4, pp. 11-14.

19. ViralZone

(2020).Available

at: http://viralzone.expasy.org/all_by_species/53.html.

20. Gregory J. Hannon. 2002. RNA interference. Nature, 2002, vol. 418, no. 8, pp. 244-251.https://doi.org/10.1038/418244a.

21. Knorr D.A., Mullin R.H., Hearne P.Q., Morris T.J. 1991. De novo generation of defective interfering RNAs of tomato bushy stunt virus by high multiplicity passage. Virology, 1991, vol. 181, no.1, pp.193-202. https://doi.org/10.1016/00426822(91)90484-S.

22. Scholthof H.B., Morris T.J., Jackson A.O. 1993. The capsid protein gene of tomato bushy stunt virus is dispensable for systemic movement and can be replaced for localized expression of foreign genes. Mol Plant-Microbe Interact, 1993, vol.6, no.3, pp. 309-322.https://doi.org/10.1094/MPMI-6-309.

23. Hearne P.Q., Knorr D.A., Hillman B.I., Morris T.J. 1990. The complete genome structure and synthesis of infectious RNA from clones of tomato bushy stunt virus. Virology, 1990, vol.177, no.1, pp. 141-151. https://doi.org/10.1016/00426822(90)90468-7.

24. Freund J. 1956. The mode of action of immunologic adjuvants. Bibl. Tuberc., 1956, no.10, pp. 130-148. https://doi.org/(10):130-148.

25. Sagi M., Fluhr R., Lips S.H. 1999. Aldehyde oxidase and xanthine dehydrogenase in a flacca tomato mutant with deficient abscisic acid and wilty phenotype. Plant Physiol., 1999, vol. 120, no.2, pp. 571-578. https://doi.org/10.1104/pp.120.2.571.

26. Sagi M., Omarov R.T., Lips S.H. 1998. The Mo-hydroxylases xanthine dehydrogenase and aldehyde oxidase in ryegrass as affected by nitrogen and salinity. Plant Sci. 1998, vol. 135, no.2, pp. 125-135. https://doi.org/10.1016/S01689452(98)00075-2.

27. Zarepour M., Simon K., Wilch M., Nielander U., Koshiba T., Seo M., Lindel T., Bittner F. 2012. Identification of superoxide production by Arabidopsis thaliana aldehyde oxidases AAO1 and AAO3. Plant Mol. Biol., 2012, vol. 80, pp. 659-671. https://doi.org/10.1007/s11103-012-9975-1.

28. Weydert C.J., Cullen J.J. 2010. Measurement of superoxide dismutase, catalase and glutathione peroxidase in cultured cells and tissue. Nat. Protoc. 2010, vol. 5, no.1, pp. 51-66.https://doi.org/10.1007/s11103-012-9975-1.

29. Laemmli U.K. 1970. Cleavage of structural proteins during the assembly of the head of bacteriophage T4. Nature, vol. 15, no.5259, pp. 680685.https://doi.org/10.1038/227680a0.

30. Bradford M.M. 1976. A rapid and sensitive method for the quantitation of microgram quantities of protein utilizing the principle of protein-dye binding. Anal. Biochem, 1976, vol. 72, pp. 248-254.https://doi.org/10.1016/0003-2697(76)90527-3

31. Ibrahim E. A. Seed priming to alleviate salinity stress in germinating seeds //Journal of Plant Physiology. - 2016. - T. 192. - C. 38-46. 
32. Paparella S. et al. 2015. Seed priming: state of the art and new perspectives. Plant cell reports, 2015, vol. 34, no. 8, pp. 1281-1293.https://doi.org/10.1007/s00299015-1784-y.

33. Abraha B., Yohannes G. 2013. The role of seed priming in improving seedling growth of maize (Zea mays L.) under salt stress at field conditions. Agricultural Sciences, 2013, vol. 12, no. 4, pp. 666-672.http://dx.doi.org/10.4236/as.2013.412089.

34. Georgia Tanou, Vasileios Fotopoulos and Athanassios Molassiotis.2012. Priming against environmental challenges and proteomics in plants: update and agricultural perspectives. Frontiers in Plant Science, 2012, vol. 3, no. 216, pp. 15.https://doi.org/10.3389/fpls.2012.00216

35.Uwe Conrath. 2011. Molecular aspects of defence priming. Trends in Plant Science, 2011, vol. 16, no. 10, pp. 524-531. https://doi.org/10.1016/j.tplants.2011.06.004

36. Georgia Tanou, Panagiota Filippou, Maya Belghazi, Dominique Job, Grigorios Diamantidis, Vasileios Fotopoulos, Athanassios Molassiotis. 2012. Oxidative and nitrosative based signaling and associated post-translational modifications orchestrate the acclimation of citrus plants to salinity stress. The plant journal, 2012, vol. 72, no. 4, pp. 585-599.https://doi.org/10.1111/j.1365-313X.2012.05100.x.

37. Athanassios Molassiotis, Georgia Tanou, Grigorios Diamantidis.2010. NO says more than 'YES' to salt tolerance Salt priming and systemic nitric oxide signaling in plants. Plant Signaling \& Behavior, 2010, vol. 5, no. 3, pp. 209212.https://doi.org/10.4161/psb.5.3.10738

38. Rubén Alcázar, Teresa Altabella, Francisco Marco, Cristina Bortolotti, Matthieu Reymond, Csaba Koncz, Pedro Carrasco, Antonio F. Tiburcio.2010. Polyamines: molecules with regulatory functions in plant abiotic stress tolerance. Horticulture Research, 2010, vol. 231, no. 6, pp. 12371249.https://doi.org/10.1007/s00425-010-1130-0

39. Karine Gallardo, Claudette Job, Steven P.C. Groot, Magda Puype, Hans Demol, Joël Vandekerckhove, Dominique Job. 2001. Proteomic Analysis of Arabidopsis Seed Germination and Priming. Plant Physiology, 2001, vol. 126, no. 2, pp. 835848.https://doi.org/10.1104/pp.126.2.835

40. Asselberg B. 2008. Abscisic acid deficiency leads to rapid activation of tomato defence responses upon infection with Erwiniachrysanthemi. Molecular Plant Pathology, 2008, vol. 9,no.1, pp. 11-24.https://doi.org/10.1111/j.13643703.2007.00437.x

41. Mittler R., Blumwald E. 2010. Genetic engineering for modern agriculture:challenges and perspectives. Annual Review of Plant Biology, 2010, vol.61, pp. 443-462.https://doi.org/10.1146/annurev-arplant-042809-112116.

42. Foyer C. H. et al. 2016. Cross-tolerance to biotic and abiotic stresses in plants: a focus on resistance to aphid infestation. Journal of experimental botany, 2016, vol. 67, no. 7, pp. 2025-2037.https://doi.org/10.1093/jxb/erw079.

43. Yalpani N., Enyedi A.J., Leon J., Raskin I. 1994. Ultraviolet light and ozone stimulate accumulation of salicylic acid, pathogenesis-related proteins and virus resistance in tobacco. Planta, 1994, vol.193, pp. 372376.https://doi.org/10.1007/BF00201815.

44. Cheong Y.H. Chang H.S., Gupta R., Wang X., Zhu T., Luan S. 2002. Transcriptional profiling reveals novel interactions between wounding, pathogen, abiotic stress, and hormonal responses in Arabidopsis. Plant Physiology, 2002, vol.129, pp. 661-677.https://doi.org/10.1104/pp.002857.

45. Xia X. J. et al. 2015. Interplay between reactive oxygen species and hormones in the control of plant development and stress tolerance. Journal of 
experimental botany, 2015, vol. 66, no. $10, \quad$ pp. 28392856.https://doi.org/10.1093/jxb/erv089.

46. Anderson J.P., Desmond O.J., Ehlert C., Kazan K. 2004. Antagonistic interaction between abscisicasid and jasmonate-ethylene signaling pathways modulates defense gene expression and disease resistance in Arabidopsis. The Plant Cell, 2004, vol.16, pp. 3460-3479.https://doi.org/10.1105/tpc.104.025833.

47. Moldakimova N.A., Mukiyanova G.S., Yarmolinsky D.G., Brychkova G.G., Scholthof H.B., Sagi M., Omarov R.T. 2012. Effect of salinity on viral desease spread in plants.Journal of Stress Physiology and Biochemistry, 2012, vol.8, no.3, pp. 17-21.

48. Majsec K.,Pusic P. 2010. Impact of stress on the plant's ability to fight against a pathogen. Summer school of Science, Visnjan, 2010, pp.234-242.

\section{ЭФФЕКТ ПЕРЕКРЕСТНОЙ ТОЛЕРАНТНОСТИ У NICOTIАNА ВЕNTНАМІАNA ПРАЙМИНГА СЕМЯН И ВИРУСНОЙ ИНФЕКЦИИ}

Дильдабек А., Ильясова А.Б Стамгалиева Ж., Мадиров А., Касенова С., Жангазин С., Массалимов Ж., Акбасова А.

Евразийский Наииональный университет им. Л.Н. Гумилева ул.Сатпаева, 2, Нур-Султан, 010000, Казахстан

\section{АБСТРАКТ}

В настоящее время засоление почв является одним из факторов, определяющих продуктивность сельскохозяйственных культур. Во избежание какого-либо серьезного воздействия биотического и абиотического стрессов применяется метод прайминга семян. Праймированное семя сохраняет сигнальный путь сопротивления для наступающих стрессовых условий. Во время биотического и абиотического стресса сначала накапливаются активные формы кислорода, которые являются вторичными молекулами-мессенджерами во многих сигнальных путях растительных организмов. Чрезмерное количество активных форм кислорода приводит к повреждению макромолекул, таких как липиды клеточных стенок, белки, нуклеиновые кислоты. Чтобы преодолеть серьезный эффект, $\mathbf{y}$ растений развивались ферментативные и неферментативные системы защиты. Ключевыми ферментами являются каталаза, альдегидоксидаза, супероксиддисмутаза. Основными компонентами неферментативной антиоксидантной системы являются витамины, низкомолекулярные вещества, такие как глутатион. Феномен «перекрестной толерантности» предполагает устойчивость растительного организма к одному стрессу при воздействии другого. Раннее воздействие солевого стресса на Nicotiana benthamiana приводит к его устойчивости к вирусной инфекции, изменению активности антиоксидантных ферментов (каталазы, альдегидоксидазы). Анализ вирусных частиц выявил снижение содержания вирусных частиц в праймированных солью растениях.

Ключеыве слова: соленость, праймирование, вирусная инфекция, перекрестная толерантность, активные формы кислорода. 
Дильдабек А., Ильясова А.Б Стамгалиева Ж., Мадиров А., Касенова С., Жангазин С., Массалимов Ж., Акбасова А.

Евразийский Национальный университет им. Л.Н. Гумилева ул.Сатпаева, 2, Нур-Султан, 010000, Казахстан

\section{ТYЙІН}

Қазіргі уақытта топырақтың тұздануы ауыл шаруашылығы дақылдарының өнімділігін анықтайтын факторлардың бірі болып табылады. Ауыр жағдайларда өсімдіктерде сабақтары мен тамырлардың өсуінің баяулауы, жоғары концентрациялардағы тұздардың биохимиялық және физиологиялық әсерінен өнімділіктің төмендеуі анықталады. Биотикалық және абиотикалық стресстердің қандай да бір елеулі әсерін болдырмау үшін тұқым праймингі әдісі қолданылады. Праймингтен өткен тұқым келе жатқан стресстік жағдайлар үшін кедергінің сигналдық жолын сақтайды. Биотикалық және абиотикалық стресс кезінде алдымен өсімдіктің көптеген сигналдық жолдарында екінші молекулалар-мессенджерлер болып табылатын оттегінің белсенді түрлері жинақталады. Оттегінің белсенді формаларының шамадан тыс мөлшері жасушалық қабырғалардың липидтері, ақуыздары, нуклеин қышқылдары сияқты макромолекулалардың зақымдануына әкеледі. Елеулі әсерді жеңу үшін өсімдіктерде ферментативті және ферментативті емес қорғау жүйелері дамыды. Негізгі ферменттер-каталаза, альдегидоксидоксид, супероксидисмутаза. Ферментативті емес антиоксиданттық жүйенің негізгі компоненттері-витаминдер, глутатион сияқты төмен молекулалық заттар. "Тоғыспалы төзімділік" феномені өсімдік ағзасының бір стреске төзімділігін басқаның әсерінен болжайды. Nicotiana benthamiana-ға тұзды стресстің ерте әсері оның вирустық инфекцияға төзімділігіне, антиоксиданттық ферменттердің (каталазалар, альдегидоксидазалар) белсенділігінің өзгеруіне әкеледі. Вирусты бөлшектерді талдау праймирленген тұз өсімдіктердегі вирусты бөлшектер құрамының төмендегенін анықтады. 